\title{
14
}

\section{TALKING TO MY COMMUNITY ELSEWHERE}

\section{Bringing together networked public spheres and the concept of translocal communities}

\author{
Daniel Maier, Daniela Stoltenberg, \\ Barbara Pfetsch, and Annie Waldherr
}

\section{Dynamic notions of two concepts: space and public sphere}

The concept of the public sphere, which ties political decision-making to (mediated) public debates, has significantly changed with the advancement of digitization. Thirty years ago, the reach of public debates was tied legally and economically to territories. Political information and opinions were broadcast almost exclusively through legacy media. The transmission of mass-mediated messages was closely related to spaces that overlapped with political and administrative units at the local, regional, or national levels. Media organizations, journalists, and socio-economic elite speakers constituted the mass-mediated arenas for these territories. Therefore, it is no surprise that, back then, most researchers investigated public spheres within national territories.

Drawing on the work of Benkler (2006) and Neuberger (2009), we refer to public spheres as heterogeneous and overlapping mediated networks of publicly communicating persons, organizations, and institutions. In contrast to the territorially aligned public spheres of the past, these mainly digital networked public spheres elude simple territorial attachments. The communicative connections among humans on the web and on social media transcend the borders of cities, regions, and nation states.

The advent of digital communication not only implies a structural change of public debate. Networked public spheres are also less centered on the communication of mass-mediated organizations (Benkler 2006). As a consequence, they are also much less centered on territories. However, their spatial dimension is no less important than that of their predecessors; it just does not fit the rigid territorial notion of space. Rather, we argue that we are better served by also thinking of public spheres in terms of the spatial figure (Löw 2020) of a network. While territorial spaces focus on actors drawing borders around 
themselves and their social goods, network spaces shift the perspective to the connections between these elements, even across distances (Löw 2020, 154, 159; Mol and Law 1994, 643).

To understand and describe the spatial configurations of networked public spheres, we need to revisit the nature of social media communication. We argue that the concept of communities is crucial for this purpose. Moreover, we must acknowledge that the dwindling importance of the mass media and their broadcasting territories is accompanied by the increased importance of direct communicative connections between social actors, who are located in places. That is, they are located in (geographic) locations, which are ascribed meaning and identity and which relate to other places (Löw 2020, 156). Communicative relations between social actors span the distance between their places and may be considered translocal. Here, translocality refers to the communicative construction of relations between (distant) localities through media (Hepp 2009a, 330).

On the social web (i.e., on social media platforms and in other online environments where people communicate with each other), individual users and collective actors assemble into social communication networks, which form larger communities with distinct translocal interaction patterns. Communities are networks of social actors with a shared imagination of their communion (Anderson 2006). Ties among members of imagined communities are based on a common sense of identity, such as a common language and/or socio-cultural identity (e.g., ethnic communities), a shared migration history (e.g., diasporic communities), interest in a common topic or political issue (e.g., issue communities), or affective reactions to events (e.g., affective communities).

Increased mobility, Internet-based communication, and social media platforms in particular have elevated the translocal potential of communities. Thus, we argue that the study of public communication should consider the translocal potential of communities as a signifying feature of networked public spheres. This does not mean that local or national figures have become irrelevant. Rather, we argue that communities with distinct translocal and fluid interaction patterns provide a useful and augmented description for the spatial anchoring of public communication processes on the social web.

Our argument is organized into three sections. First, we explain why territorial notions have become inadequate when researching networked public spheres. Second, we argue that (imagined) communities of users constitute the spatially anchored social underpinnings of networked public spheres on the social web. Third, we explore how digitization has led communities to increase their mobility and become more translocal, and we conclude that public sphere research should integrate the translocal potential of communities as an important analytical category. We also understand the digitization-induced spatial restructuring of public spheres as one aspect of the meta-process of what Knoblauch and Löw $(2017,3)$ coin "spatial re-figuration of the social world" (i.e., "a fundamental shift in our understanding of space”). 


\section{Territorial notions in public sphere research}

In social research, the public sphere is a basic category used to understand processes of will formation in society. The public sphere denotes an open communication system in which issues and opinions are discussed publicly and which allows the members of a society to observe and participate in the deliberation of issues and the formation of public opinion (Neidhardt 1994, 7; Habermas 1996, 360). Its general functions are openness toward issues and opinions, their validation through the public exchange of arguments, and the orientation of society on what is at stake (Neidhardt 1994, 8-10). In Habermas' (1996, 356-357) writings, the public sphere is normatively bound to democracy since the issues and opinions that are processed in the public sphere stem from the lifeworlds of the citizens and are made salient through communication as an indication of what should be tackled in the political system.

Even though Habermas $(1996,360)$ talks about the public sphere as the "social space generated in communicative action," the term space has mostly been used metaphorically and has not been a focus in much of the public sphere research (Wallner and Adolf 2014). However, due to its normative functionality for democracy (Habermas 1996), the public sphere concept is mostly and implicitly aligned with the boundaries of national political territories (Pfetsch, Heft, and Knüpfer 2019; Volkmer 2014). This presupposed alignment may have been a consensus for traditional, mass-mediated public spheres because media systems and markets tended to be structured along political and linguistic borders. However, research into online public spheres has also adopted these national boundaries. For instance, research on social media communication often maps Twitterspheres or blogospheres at the country level (e.g., Bruns and Enli 2018; Ausserhofer and Maireder 2013).

Meanwhile, other studies have focused on urban public spheres (e.g., von Saldern 2013). Moreover, over the last two decades, the concept of transnational public spheres has been established with the progress of integration in the European Union and the search for European public spheres (e.g., Koopmans and Statham 2010).

Theoretical discussions propose that digital public spheres transcend the national scope with a potentially global reach (Castells 2008). In line with Volkmer's (2014, 6) critique that public communication has become largely "disembedded" from national territories, just like the "core assets of public 'civil' culture [and] public institutions," this body of literature moves the public sphere beyond the scope of nation states. This is done explicitly in reference to the expanded communicative possibilities provided by the Internet (e.g., Pfetsch, Heft, and Knüpfer 2019).

However, even while altering the geographic scope-shrinking it down to the level of cities or extending it to whole continents and beyond-these public sphere concepts arguably remain bound to a territorial notion of space. We argue that the merely territorial figure is no longer appropriate for grasping the shape and extent of digital public spheres. Rather, the network, with its focus on relations between distant elements (Löw 2020; Mol and Law 1994), is a more fitting spatial figure. 
The nature of networked public spheres stands in stark contrast to territory-based concepts. The core features of networked public spheres are digital communicative connections among social actors, which - as we will describe in the next sectionquite naturally transcend the borders of cities, regions, and nation states (Hampton and Wellman 2003).

The inclusion of social media in many people's communication patterns has changed the structure of public communication and implies a new spatiality of public debate. Findings from existing research foreground that the most significant ties in social media communication connect the cosmopolitan centers of the world (Leetaru et al. 2013; Lin, Halavais, and Zhang 2007) and constitute a global network. At the same time, we still witness that most communication takes place within relatively short distances inside the same metropolitan area (Takhteyev, Gruzd, and Wellman 2012). The literature corroborates a clear spatial pattern: metropolitan clusters of tightly connected users emerge simultaneously with long tie connections between urban centers.

\section{Imagined communities as social underpinnings of networked public spheres}

In social terms, recent literature understands digital communication networks as the outcome of community-building processes (Stephansen and Couldry 2014). Social media communication structures represent not only "interpersonal communication, but also how people orient themselves to public life" (Swart, Peters, and Broersma 2018, 4329). These networks reflect individual users' sense of belonging and may be interpreted as support structures in people's everyday lives (Gruzd, Wellman, and Takhteyev 2011).

According to Gruzd, Wellman, and Takhteyev (2011), social media networks feature the characteristics of various community concepts (Anderson 2006; Jones 1997; McMillan and Chavis 1986). As the concept of community is normative and contested (Bourke 2010; Wellman 1979), controversial debates and diverging traditions of theorizing the concept have developed (see Blokland 2017, 15-41; Jones 1995). While tracing this development goes beyond the scope of this chapter, a short conceptualization can provide clarity.

Community has traditionally been a vital category in sociology and urban studies and is marked by two features: relationality and spatiality (Bourke 2010). In terms of relationality, it denotes both the result of social interactions between individuals and a relationship between individuals and society, driven by a desire for belonging (Bourke 2010). In terms of spatiality, the concept of community was traditionally thought of as distinctly local, namely, as "a set of social relationships operating within a specific boundary, location, or territory" (Bourke 2010, 171). This territorially bound notion of community has, however, been challenged. According to Wellman $(1979,1202)$, the notion of community as a solidarity group in a given local territory may obscure the search for true communities in present-day societies. Instead of focusing on local and close-knit groups, Wellman (1979) proposes 
looking for the sociable and supportive primary ties of individuals without being preoccupied about their location. In other words, "community is based on sociable and supportive social relations, and not on physical locality" (Gruzd, Wellman, and Takhteyev 2011, 1298).

That does not mean, however, that physical localities are insignificant for communities. Empirically, people maintain multiple, highly individualized, and geographically dispersed personal community networks (Chayko 2015). At the same time, "neighborly relationships remain important, but as a minority of ties within the overall network" (Hampton and Wellman 2003, 278-279). Against this backdrop, we define communities as follows:

Communities consist of far-flung, kinship, workplace, friendship, interest group, and neighborhood ties that concatenate to form networks providing sociability, aid, support, and social control. Communities are usually not groups, but are social networks that are sparsely knit, loosely bounded, and far flung.

(Hampton and Wellman 2003, 278)

The advent of the digital age marks a breaking point for how we conceive of communities. The rise of digital communication has facilitated the emergence of widespread interest communities (Hampton and Wellman 2003, 281). The "spaceliberating power of the Internet" allows people to connect regardless of borders and distance, potentially on a global scale (Hampton and Wellman 2003, 282). Again, this does not mean that place becomes insignificant. The potential to maintain long-distance connections must not veil the importance of physical places. Connections to others living in the same area or within close geographical reach (Gruzd, Wellman, and Takhteyev 2011; Hampton and Wellman 2003) or connections between metropolitan areas (Lin, Halavais, and Zhang. 2007) remain important parts of personal networks.

Social connections in personal networks are not fixed or given; they are invigorated in living practices and manifest in the details of everyday life (Blokland 2017, 2). These manifestations reflect that people value their communities and that "they hold imaginations of what they are" (Blokland 2017, 2). Anderson (2006) argues that shared imaginations are crucial for communities. Members of large-scale communities, such as nations, "will never know most of their fellow-members, . . yet in the minds of each lives the image of their communion" (Anderson 2006, 6). Gruzd, Wellman, and Takhteyev (2011, 1297-1298) transfer Anderson's concept of imagined communities to social media networks; users cannot know everyone in their virtual surroundings but are aware of the presence of other users as either their imagined audience when they write a message or their sources of information when they read their timeline.

Although not usually explicitly referring to the community concept, social media studies abound with references to different kinds of cohesive networks gathering around shared identities, interests, or experiences (see, e.g., Hepp 2009b). 
For example, a branch of social movement research studying new forms of collective action online has widely acknowledged the capacity of social media platforms to organize actors interested in specific topics and to create so-called issue networks (McKelvey, DiGarzia, and Rojas 2014).

Common interest in issues bears a strong potential for creating common identities and issue communities; this has been shown, for instance, in the LGBT community in London (Linfoot 2018). Likewise, although protest movements take place at specific sites (Earl et al. 2013), they are often connected translocally via social media (Bastos and Mercea 2016). Via trending hashtags, such as \#MeToo (Mendes, Ringrose, and Keller 2018) or \#Ferguson (Jackson and Foucault Welles 2016), these movements have formed counterpublic spheres.

As framing devices, hashtags not only focus attention on certain issues but also offer venues through which to share emotions and sentiment, creating affective publics which "assemble around media and platforms that invite affective attunement, support affective investment, and propagate affectively charged expression" (Papacharissi 2016, 308). Such affective communities have been observed in the aftermath of events, such as hurricanes (Shelton et al. 2014) or terrorist attacks (Lin and Margolin 2014), when people from all over the world connect to express their sympathy and emotional support.

Finally, in a world of digital communication and mobility, language and ethnicity are still crucial to identities and maintaining a sense of belonging in ethnic communities (Christiansen 2019); with respect to shared migration histories, they are also crucial to deterritorialized diasporic communities (Hepp 2009a).

All of these examples constitute imagined communities gathering around shared identities, interests, or experiences. Their network infrastructure bears an inscribed potential for translocality. However, communicative relationships on social media platforms often have their origin in real-world social relationships (Ellison, Steinfield, and Lampe 2007), which tend to develop among geographically proximate individuals. Proximity increases the likelihood of face-to-face interaction and communication and allows individuals to explore what they might have in common (Monge and Contractor 2003, 227-228). The proliferation of digital media led to a refiguration of communication networks, simultaneously strengthening local and distant relations. It helped "increase our global reach but also strengthen[ed] local communities and geographically distributed, but culturally contiguous, 'diasporas"' (Monge and Contractor 2003, 231). Although social media platforms such as Facebook or Twitter are not bound to geopolitical borders, a large share of the interactions between users still takes place within a proximate local or regional radius (Takhteyev, Gruzd, and Wellman 2012). Consequently, communicative relationships between users who are geographically distant from one another are comparatively rare. In the next section, we argue that the distribution of communicative relations resembles the structures of translocal communities. 


\section{Translocal potentials of communities in networked public spheres}

Where public sphere theory still largely remains bound to territorial notions of space, it has much to learn from community research. This trajectory of investigation highlights that, while the local remains a powerful category, shared identities and support structures now extend into more complex, translocal patterns. Blokland (2017) argues that communities feature specific roots and routes, which means that sociable and supportive ties among people are anchored in places, while also emphasizing the connections between them. Etymologically, the term translocality denotes the continued relevance of the local, but the prefix trans shifts the analytical focus to connections and in-betweenness (Hepp 2004, 163).

Translocality may be interpreted as the result of both globalization and digitization. Globalization typically describes an increase in the mobility of people, goods, and services. This mobility implies growing migration, commuting, and traveling for work and leisure for individuals and those within their network. Simultaneously, digitization enables "communicative relations across certain localities" (Hepp 2009a, 330) to an unprecedented degree. While the traditional notion of community used to be more local, digital media "allow us to communicate beyond our primary location, which suggests [that] geographical distance becomes less important for the formation and maintenance of attachments" (Wehden and Stoltenberg 2019, 1402). Translocality, therefore, focuses on interlinkages between places but does not assume a diminished importance of place: "The always-on, always accessible network produces a broad set of changes to our concept of place, linking specific locales to a global continuum and thereby transforming our sense of proximity and distance" (Varnelis and Friedberg 2008, 15). Actors link relevant places communicatively, cognitively, and emotionally (Lingenberg 2014). From this follows the notion of translocal communities.

According to Hepp (2009b), communities emerge from processes of "translocal communicative thickening." In that sense, the term translocal denotes that the local continues to be the prime anchor point of an individual's lifeworld. Communicative densifications, however, are increasingly oriented toward other specific places (or individuals in other places) beyond geopolitical territories.

In line with this argument, we propose that networked public spheres often emerge from such communities. Of course, these communities are not congruent with public spheres, and many communities do not constitute public spheres per se. For a public sphere to emerge from an imagined community, in addition to a shared identification and a generalized communicative densification between its members, activation around an issue is required. However, if communities are spatially distributed following ethnic, commercial, political, and religious communitizations (Hepp 2009b), then they will strongly shape where and for whom an event becomes an issue. Through the formation of translocal ties, they therefore influence the emergence of issue-specific "communicative thickening" between particular places. 


\section{Concluding remarks}

Networked public spheres provide a framework for considering the emergence, meaning, and consequences of digital public communication and connections. However, due to the lack of theorization, the concept either neglects the spatial dimension of public communication on the social web or adopts inappropriate territorial notions. We have laid out an argument for integrating the notion of translocal communities into this line of research.

Under conditions of increased global mobility and connections, translocal communities form around shared notions of identity, interest, and experience. Digital media enable this process by providing opportunity structures for members of these imagined communities to connect with and potentially support one another. We argue that these communities are the social underpinnings of many networked public spheres, as they can become activated around shared issues. Conceiving of communities as the social foundation of public spheres not only elevates the importance of space but also emphasizes that social mechanisms are a driving force of structure in networked public spheres. Thus, the underlying spatial figure of networked public spheres is better described as a translocal network of places rather than a contiguous territory.

Translocality therefore proves to be a valuable lens for the study of (networked) public spheres. It is our conviction that it can help us more fully understand spatially structured but non-locally bound communication phenomena, such as international protest movements, social media trends, or discourses on transnational political problems.

Moreover, our sketch of the spatial reformation of the public sphere concept feeds into the meta-process of the refiguration of space (Knoblauch and Löw 2017). The social web may be understood as an opportunity structure for social actors to build networks. Those actors are place-bound, locally anchored nodes that connect with others, potentially across large distances and beyond the borders of cities, nation states, or even continents. While the network structure itself bears an inscribed potential for translocality, research findings support that network-building processes are often based on homophily; shared social identities, interests, or experiences increase the likelihood of community networks to be formed among similar actors. All of these features are, of course, not independent of the local embeddings and relational positions of actors in their networks. Likewise, transforming the community into a public sphere requires the activation of the network through a shared public issue. Thus, we may conclude that the spatial features of networked public spheres strongly adhere to the social mechanisms of translocal community building.

\section{Acknowledgements}

This research has been funded by the Deutsche Forschungsgemeinschaft (DFG, German Research Foundation)—project number 290045248—SFB 1265.

\section{References}

Anderson, Benedict. 2006. Imagined Communities: Reflections on the Origin and Spread of Nationalism, 3rd ed. London: Verso books. 
Ausserhofer, Julian, and Axel Maireder. 2013. "National Politics on Twitter: Structures and Topics of a Networked Public Sphere.” Information, Communication \& Society 16 (3): 291314. doi: 10.1080/1369118X.2012.756050.

Bastos, Marco Toledo, and Dan Mercea. 2016. "Serial Activists: Political Twitter Beyond Influentials and the Twittertariat." New Media \& Society 18 (10): 2359-2378. doi: $10.1177 / 1461444815584764$.

Benkler, Yochai. 2006. The Wealth of Networks: How Social Production Transforms Markets and Freedom. New Haven: Yale University Press.

Blokland, Talja. 2017. Community as Urban Practice. Cambridge: Polity.

Bourke, Alan Gerard. 2010. "Community." In Encyclopedia of Urban Studies, edited by Ray Hutchison, 171-175. Los Angeles: Sage.

Bruns, Axel, and Gunn Enli. 2018. "The Norwegian Twittersphere: Structure and Dynamics." Nordicom Review 39 (1): 129-148. doi: 10.2478/nor-2018-0006.

Castells, Manuel. 2008. "The New Public Sphere: Global Civil Society, Communication Networks, and Global Governance." The Annals of the American Academy of Political and Social Science 616 (1): 78-93. doi: 10.1177/0002716207311877.

Chayko, Mary. 2015. "The First Web Theorist? Georg Simmel and the Legacy of 'The Web of Group-affiliations'.” Information, Communication \& Society 18 (12): 1419-1422. doi: 10.1080/1369118X.2015.1042394.

Christiansen, Sidury M. 2019. “'Listisimo para los \#XVdeRubi’: Constructing a Chronotope as a Shared Imagined Experience in Twitter to Enact Mexicanness Outside of Mexico.” Lingua 225: 1-15. doi: 10.1016/j.lingua.2019.05.002.

Earl, Jennifer, Heather McKee Hurwitz, Analicia Mejia Mesinas, Margaret Tolan, and Ashley Arlotti. 2013. "This Protest Will Be Tweeted: Twitter and Protest Policing during the Pittsburgh G20.” Information, Communication \& Society 16 (4): 459-478. doi: 10.1080/1369118X.2013.777756.

Ellison, Nicole B., Charles Steinfield, and Cliff Lampe. 2007. "The Benefits of Facebook 'Friends': Social Capital and College Students' Use of Online Social Network Sites." Journal of Computer-Mediated Communication 12 (4): 1143-1168. doi: 10.1111/j.1083-6101.2007.00367.x.

Gruzd, Anatoliy, Barry Wellman, and Yuri Takhteyev. 2011. "Imagining Twitter as an Imagined Community." American Behavioral Scientist 55 (10): 1294-1318. doi: 10.1177/0002764211409378.

Habermas, Jürgen. 1996. Between Facts and Norms: Contributions to a Discourse Theory of Law and Democracy. Cambridge: Polity.

Hampton, Keith, and Barry Wellman. 2003. "Neighboring in Netville: How the Internet Supports Community and Social Capital in a Wired Suburb." City \& Community 2 (4): 277-302. doi: 10.1046/j.1535-6841.2003.00057.x.

Hepp, Andreas. 2004. Netzwerke der Medien. Medienkulturen und Globalisierung. Wiesbaden: Springer VS.

Hepp, Andreas. 2009a. "Localities of Diasporic Communicative Spaces: Material Aspects of Translocal Mediated Networking." The Communication Review 12 (4): 327-348. doi: 10.1080/10714420903344451.

Hepp, Andreas. 2009b. "Transculturality as a Perspective: Researching Media Cultures Comparatively." Forum Qualitative Sozialforschung/Forum: Qualitative Social Research 10 (1). doi: 10.17169/fqs-10.1.1221.

Jackson, Sarah J., and Brooke Foucault Welles. 2016. "\#Ferguson is Everywhere: Initiators in Emerging Counterpublic Networks." Information, Communication \& Society 19 (3): 397-418. doi: 10.1080/1369118X.2015.1106571.

Jones, Quentin. 1997. "Virtual-Communities, Virtual Settlements \& Cyber-Archaeology: A Theoretical Outline." Journal of Computer-Mediated Communication 3 (3). doi: 10.1111/ j.1083-6101.1997.tb00075.x. 
Jones, Steven G. 1995. "Community in the Information Age." In Cybersociety. ComputerMediated Communication and Community, edited by Steven G. Jones, 138-163. Thousand Oaks: Sage.

Knoblauch, Hubert, and Martina Löw. 2017. "On the Spatial Re-figuration of the Social World.” Sociologica 11 (2): 1-27. doi: 10.2383/88197.

Koopmans, Ruud, and Paul Statham, eds. 2010. The Making of a European Public Sphere: Media Discourse and Political Contention. New York: Cambridge University Press.

Leetaru, Kalev H., Shaowen Wang, Guofeng Cao, Anand Padmanabhan, and Eric Shook. 2013. "Mapping the Global Twitter Heartbeat: The Geography of Twitter." First Monday 18 (5). doi: 10.5210/fm.v18i5.4366.

Lin, Jia, Alexander Halavais, and Bin Zhang. 2007. "The Blog Network in America: Blogs as Indicators of Relationships Among US Cities." Connections 27 (2): 15-23. www.insna. org/Connections-Web/Volume27-2/Lin.pdf.

Lin, Yu-Ru, and Drew Margolin. 2014. "The Ripple of Fear, Sympathy and Solidarity During the Boston Bombings." EPJ Data Science 3: 31. doi: 10.1140/epjds/ s13688-014-0031-z.

Linfoot, Matthew. 2018. "Queer in Your Ear: Connecting Space, Community, and Identity in LGBT BBC Radio Programs, 1992-2000." Journal of Radio \& Audio Media 25 (2): 195-208. doi: 10.1080/19376529.2018.1473402.

Lingenberg, Swantje. 2014. "Mobilisiert-mediatisierte Lebenswelten und der Wandel des öffentlichen Raums." In Medienkommunikation in Bewegung, edited by Jeffrey Wimmer and Maren Hartmann, 69-86. Wiesbaden: Springer VS. doi: 10.1007/978-3-531-19375-5.

Löw, Martina. 2020. "In welchen Räumen leben wir? Eine raumsoziologisch und kommunikativ konstruktivistische Bestimmung der Raumfiguren Territorialraum, Bahnenraum, Netzwerkraum und Ort." In Grenzen der Kommunikation-Kommunikation an den Grenzen, edited by Jo Reichertz, 149-164. Weilerswist: Velbrück.

McKelvey, Karissa, Joseph DiGrazia, and Fabio Rojas. 2014. “Twitter Publics: How Online Political Communities Signaled Electoral Outcomes in the 2010 US House Election." Information, Communication \& Society 17 (4): 436-450. doi: 10.1080/1369118X.2014.892149.

McMillan, David W., and David M. Chavis. 1986. "Sense of Community: A Definition and Theory." Journal of Community Psychology 14 (1): 6-23. doi: 10.1002/1520-6629(198601)14:1<6::AID-JCOP2290140103>3.0.CO;2-I.

Mendes, Kaitlynn, Jessica Ringrose, and Jessalynn Keller. 2018. "\#MeToo and the Promise and Pitfalls of Challenging Rape Culture Through Digital Feminist Activism." European Journal of Women's Studies 25 (2): 236-246. doi: 10.1177/1350506818765318.

Mol, Annemarie, and John Law. 1994. "Regions, Networks and Fluids: Anaemia and Social Topology." Social Studies of Science 24 (4): 641-671. doi: 10.1177/030631279402400402.

Monge, Peter R., and Noshir S. Contractor. 2003. Theories of Communication Networks. New York: Oxford University Press.

Neidhardt, Friedhelm. 1994. "Öffentlichkeit, öffentliche Meinung, soziale Bewegungen." In Öffentlichkeit, öffentliche Meinung, soziale Bewegungen, edited by Friedhelm Neidhardt, 7-41. Opladen: Westdeutscher Verlag.

Neuberger, Christoph. 2009. "Internet, Journalismus und Öffentlichkeit. Analyse des Medienumbruchs." In Journalismus im Internet, edited by Christoph Neuberger, Christian Nuernbergk, and Melanie Rischke, 19-105. Wiesbaden: Springer VS.

Papacharissi, Zizi. 2016. "Affective Publics and Structures of Storytelling: Sentiment, Events and Mediality." Information, Communication \& Society 19 (3): 307-324. doi: 10.1080/1369118X.2015.1109697.

Pfetsch, Barbara, Annett Heft, and Curd Knüpfer. 2019. "Transnationale Öffentlichkeiten in der Digitalen Gesellschaft: Konzepte und Forschungsperspektiven." In Politik in der 
digitalen Gesellschaft, edited by Jeanette Hofmann, Norbert Kersting, Claudia Ritzi, and Wolf J. Schünemann, 83-101. Bielefeld: transcript.

Shelton, Taylor, Ate Poorthuis, Mark Graham, and Matthew Zook. 2014. "Mapping the Data Shadows of Hurricane Sandy: Uncovering the Sociospatial Dimensions of 'Big Data'." Geoforum 52: 167-179. doi: 10.1016/j.geoforum.2014.01.006.

Stephansen, Hilde C., and Nick Couldry. 2014. "Understanding Micro-Processes of Community Building and Mutual Learning on Twitter: A 'Small Data' Approach.' Information, Communication \& Society 17 (10): 1212-1227. doi: 10.1080/1369118X.2014.902984.

Swart, Joëlle, Chris Peters, and Marcel Broersma. 2018. "Shedding Light On the Dark Social: The Connective Role of News and Journalism in Social Media Communities." New Media \& Society 20 (11): 4329-4345. doi: 10.1177/1461444818772063.

Takhteyev, Yuri, Anatoliy Gruzd, and Barry Wellman. 2012. "Geography of Twitter Networks." Social Networks 34 (1): 73-81. doi: 10.1016/j.socnet.2011.05.006.

Varnelis, Kazys, and Anne Friedberg. 2008. "Place: The Networking of Public Space. In Networked Publics, edited by Kazys Varnelis, 15-42. Cambridge, MA: MIT Press.

Volkmer, Ingrid. 2014. The Global Public Sphere: Public Communication in the Age of Reflective Interdependence. Cambridge: John Wiley \& Sons.

von Saldern, Adelheid. 2013. "Großstädtische Kommunikation im Wandel—Das 20. Jahrhundert." In MediaPolis-Kommunikation zwischen Boulevard und Parlament, edited by Barbara Pfetsch, Janine Greyer, and Joachim Trebbe, 23-50. Konstanz: UVK.

Wallner, Cornelia, and Marian Adolf. 2014. "Räume und Kontexte öffentlicher Kommunikation." In Medienkommunikation in Bewegung, edited by Jeffrey Wimmer and Maren Hartmann, 87-101. Wiesbaden: Springer VS.

Wehden, Lars-Ole, and Daniela Stoltenberg. 2019. "So Far, Yet So Close: Examining Translocal Twitter Audiences of Regional Newspapers in Germany." Journalism Studies 20 (10): 1400-1420. doi: 10.1080/1461670X.2018.1520609.

Wellman, Barry. 1979. "The Community Question: The Intimate Networks of East Yorkers." American Journal of Sociology 84 (5): 1201-1231. 